\title{
EVALUATION OF AFLATOXIN CONTAMINATION AND QUALITY OF NUTS IN EGYPTIAN MARKETS AND AFTER COLD STORAGE
}

\author{
Hoda A. Galal \\ Environmental Studies and Research Institute (ESRI), Univ. of Sadat City (USC), \\ Menofeia, Egypt. \\ Corresponding author: hoda.galal@esri.usc.edu.eg, hodagalal2002@yahoo.com
}

Received: Feb. 18, 2017

Accepted: Mar. 4, 2017

\begin{abstract}
Aflatoxins (AFs) are secondary metabolites produced by toxigenic fungi in the field or during storage. A total of 72 in-shell and shell-less samples of almonds, hazelnuts and walnuts were collected from small retails and hyper-Egyptian markets from middle June to middle July of 2015. This is the period of the holy month of Ramadan in Islamic calendar; the main season for consuming nuts in Egypt. Fruit quality and aflatoxins contamination including $A F B_{1}, A F B_{2}, A F G_{1}, A F G_{2}$ and total AFs were measured after collecting samples from market, and after six months of cold storage, at $7^{\circ} \mathrm{C}$ and $70 \%$ relative humidity, using high performance liquid chromatography (HPLC). All nut samples collected from small retails and hyper-markets were free from AFs. After six months of cold storage, only one sample of shell-less almonds recorded $1.6 \mu \mathrm{g} \mathrm{AFG} / \mathrm{kg}$ kernels. Nut quality had deteriorated after storage, especially for shellless walnuts and shell-less hazelnuts, compared to other nuts. We concluded that storage of inshell nuts is preferred than the shell-less ones to keep good taste, avoid insect and fungal infection, and to protect nuts from AFs contamination. Strict quarantine of nuts and other imported food products is important to ensure food safety and AFs free.
\end{abstract}

Key words: Aflatoxin, nuts, cold storage, HPLC

\section{INTRODUCTION}

Nuts is a common term refers to any fruit with hard-shell and edible kernel. It includes number of species such as almond, Brazil nut, hazelnut, pecan, pistachio, walnut, etc. Nuts are a good source of energy and nutrients. They contain a relatively large quantity of calories, essential unsaturated fatty acids, amino acids, minerals and vitamins (Kris-Etherton et al, 1999 and Kornsteiner-Krenn et al., 2013). Nuts in the Egyptian markets are imported from foreign countries. Almond (Prunus amygdalus L.) and hazelnut (Corylus avellana L.) are produced mainly in Mediterranean countries and the United States, as well as Asia for almond, while, walnut (Jugland spp. L.) is produced in temperate zone of the Northern Hemisphere, particularly in the United States (FAO, 1994 and FAO, 2013). Imported nuts are stored and consumed all over the year, especially in Ramadan.
Unfortunately, storing nuts in unsuitable conditions causes aflatoxins (AFs) contamination and some biochemical changes that eventually affect kernels quality and may cause huge economic losses (Christopoulos and Tsantili, 2012 and Raisi et al., 2015) .

Aflatoxins are a group of toxic metabolites called "mycotoxins". They are produced by Aspergillus spp. moulds, especially Aspergillus flavus and Aspergillus parasiticus (Leontopoulos et al., 2003 and Zhang et al., 2014). About 20 forms of AFs were identified, but the most prevalent and toxic forms are $\mathrm{AFB}_{1}, \mathrm{AFB}_{2}, \mathrm{AFG}_{1}$ and $A F G_{2}$. Food contamination with $A F s$ is very dangerous to human body. Aflatoxins can cause many health risks as they are carcinogenic and can cause both acute and chronic toxicity (Wild and Gong, 2010). Aflatoxins contamination had been confirmed in many kinds of nuts in many 
countries such as; South Korea, Malaysia, Turkey, Pakistan, Saudi Arabia, and Iran (Chun et al., 2007, Leong et al., 2010, Luttfullah and Hussain, 2011, Deabes and Al-Habib, 2011, Dini, 2013). This contamination depends on several factors during pre- and post-harvest stages, such as water availability, plant nutrition, temperature, humidity, oxygen, carbon dioxide, insects, rodents infestation, fungal infection, transportation method, drying process, storage conditions, and storage period (Saleemullah et al., 2006, Embaby, 2012, Georgiadou et al., 2012, Fani et al., 2013). Although aflatoxins contamination had been reported in Egypt in many products, such as milk, wheat, rice and maize, few data were obtained about nuts and their products.

Storage conditions have a dramatic effect on nuts quality. They can cause many biochemical changes that affect kernels taste and odor. Unfavorable conditions have effect on weight loss, respiration rate, total phenoles, total antioxidant capacity, fatty acids composition, and oxidation stability. These changes may cause off-flavor, rancidity, browning and other characteristics that end up with unacceptable nuts for consumption (Lopez et al., 1995, Christopoulos and Tsantili, 2012, Raisi et al., 2015). Therefore, this study was conducted to screen AFs contamination in three types of imported nuts (almond, hazelnut, and walnut) collected from Egyptian markets (small retails and hyper-markets). This study is also comparing AFs content and fruit quality of in-shell and shell-less nuts after six months of cold storage $\left(7^{\circ} \mathrm{C}\right.$ and $\left.70 \% \mathrm{RH}\right)$.

\section{MATERIALS AND METHODS Samples collection}

A total of 72 in-shell and shell-less fruit samples of almond (Prunus amygdalus), hazelnut (Corylus avellana) and walnut (Jugland spp.) were collected randomly from small retails and hypermarkets (two kilograms for each sample) at different Egyptian governorates from middle
June to middle July of 2015 (Ramadan). Samples were collected in plastic bags (250 $\mathrm{g} / \mathrm{bag}$ ). Aflatoxins content and fruit quality were assessed firstly after collecting samples. Then, these characters were reassessed after six months of cold storage at $7^{\circ} \mathrm{C}$ and $70 \% \mathrm{RH}$.

\section{Sensory evaluation}

Taste score was carried out before and after storage by 25 panelists ( 10 male and 15 female, with age range of 20-45 years). Taste quality was scored as excellent, very good, good and bad, and any abnormal flavor was listed. Water was used to rinse the mouth between each tasting.

Insect and fungal infections were observed for shell-less nuts. While for inshell nuts, twenty fruit were randomly collected and shell were removed for this observation.

\section{Aflatoxins contamination}

Individual forms of $\mathrm{AFB}_{1}, \mathrm{AFB}_{2}, \mathrm{AFG}_{1}$, $A F G_{2}$ and total Aflatoxin (AFs) were determined as $\mu \mathrm{g} / \mathrm{kg}$ fresh weight. Fifty grams of each examined sample without shell were fine grounded and extracted using $100 \mathrm{ml}$ of acetonitrile/water solution $(9: 1 \mathrm{v} / \mathrm{v})$, and then purified by immunoaffinity column. Aflatoxins level were conducted using high performance liquid chromatography (HPLC) according to AOAC (2012) at the Regional Center for Food and Feed, Agricultural Research Center), Ministry of Agriculture (Accredited lab according to ISO/IEC 17025 from A2LA. The limit of detection was $0.007 \mu \mathrm{g} / \mathrm{L}$ (equivalent to $0.014 \mu \mathrm{g} / \mathrm{kg}$ content in samples).

\section{Statistical analysis}

Data were analyzed using Excel 2010, and mean values were calculated.

\section{RESULTS AND DISCUSSION Aflatoxins contamination}

Chromatograms obtained for standard solution, contaminated and free AFs samples of in-shell and shell-less almonds, 
hazelnuts and walnuts collected from Egyptian markets during Ramadan 2015 are shown in figures 1,2 and 3. Results of 72 nut samples analyzed for aflatoxins before and after six months of cold storage are summarized in Table 1. Results indicated that all collected samples from different Egyptian markets of in-shell and shell-less almonds, hazelnuts, and walnuts were free from all forms of aflatoxins. These results are agree with Jelinek et al. (1989) who noticed that almonds, hazelnuts and walnuts are considered at lower risk of aflatoxins contamination. Also Chun et al. (2007) in South Korea reported that walnuts are free from AFs compared to pistachio, peanuts and peanut products. In Qatar, Abdulkadar et al. (2000) reported that collected nut samples of in-shell almonds, shell-less almonds, shell-less walnuts and in-shell hazelnuts were free from AFs, while they detected contamination in pistachio and peanuts. In Portuguese market, only 1 out of 21 examined samples of almonds was contaminated with $4.97 \mu \mathrm{gg} / \mathrm{kg}$ of AFs (Rodrigues et al., 2012). On contrast, high aflatoxins contamination in nuts has been reported earlier in many countries. In Saudi Arabia, Deabes and Al-Habib (2011) detected 60,40 and $40 \%$ contaminated samples with $\mathrm{AFB}_{1}$ of in-shell walnuts, almonds and hazelnuts, respectively. In Pakistan, Luttfullah and Hussain (2011) reported different percentage of AFs contamination (30\%, $40 \%$ and $70 \%$ ) in shell-less almonds, in-shell walnuts and shell-less walnuts, respectively. In Malaysia, Leong et al. (2010) reported that $16.3 \%$ of tested nuts and commercial nut products were contaminated with AFs ranging from 17.2 to $350 \mu \mathrm{g} / \mathrm{kg}$. These percentages of contamination were very high compared to our results. The high level of AFs contamination in these countries may be attributed to that most of these countries are nut production regions, where fruit are prone to fungal contamination in the field and during pre- and post-harvest stages (Embaby et al., 2012), in addition to unfavorable storage conditions or long period of storage (Georgiadou et al., 2012, Fani et al., 2013). Whereas in imported countries, like Egypt, there are regulations to determine the limited concentration of AFs in food and feed products, and hence imported food products are subjected to strict quarantine tests before entering the country to ensure the safety and freedom of AFs.

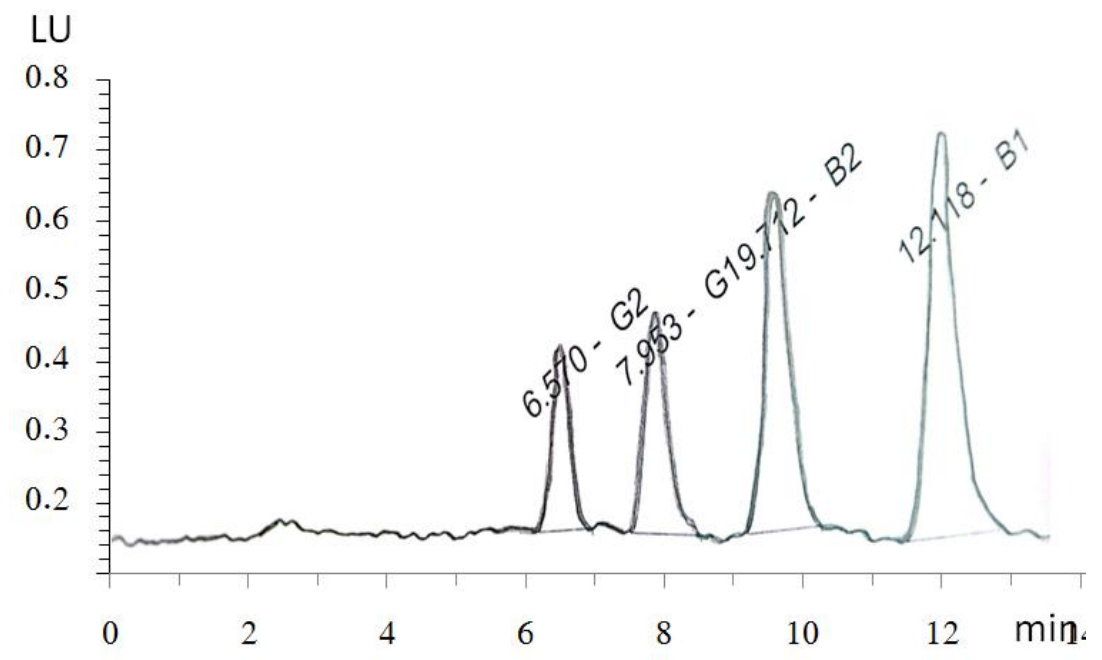

Fig. 1.Chromatogram of AFs standard solution. 


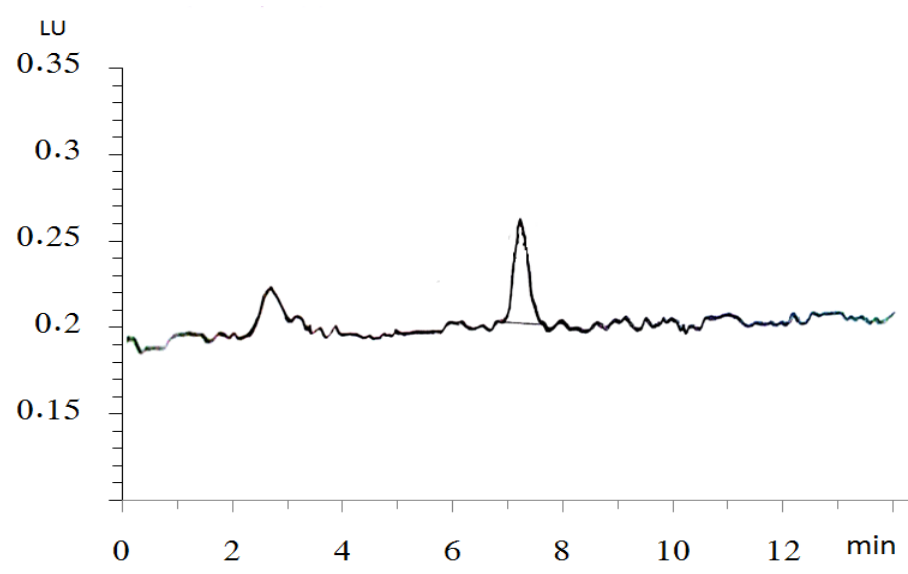

Fig. 2. Chromatogram of AFs contaminated shell-less almond.

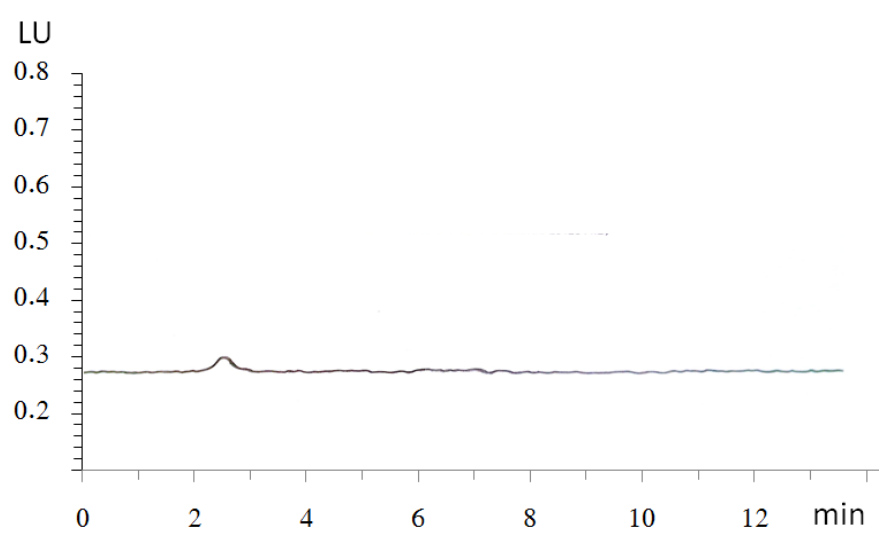

Fig. 3. Chromatogram of non-contaminated in-shell and shell-less samples of almonds, hazelnuts and walnuts collected from Egyptian markets during Ramadan 2015.

Table 1: Aflatoxins $(\mu \mathrm{g} / \mathrm{kg})$ in nut samples before and after six months of cold storage.

\begin{tabular}{|c|c|c|c|c|c|c|}
\hline \multirow[t]{2}{*}{ Samples type } & \multirow[t]{2}{*}{ market } & \multirow[t]{2}{*}{$\begin{array}{c}\text { Number } \\
\text { of } \\
\text { samples }\end{array}$} & \multicolumn{2}{|c|}{$\begin{array}{c}\begin{array}{c}\text { Number of } \\
\text { contaminated }\end{array} \\
\text { samples }\end{array}$} & \multicolumn{2}{|c|}{$\begin{array}{c}\text { Mean of AFs } \\
\text { (detected forms) }\end{array}$} \\
\hline & & & before & after & before & after \\
\hline \multirow[t]{2}{*}{ In-shell almonds } & Hyper & 6 & - & - & - & - \\
\hline & small & 6 & - & - & - & - \\
\hline \multirow[t]{2}{*}{ Shell-less almonds } & hyper & 6 & - & - & - & - \\
\hline & small & 6 & - & 1 & - & $\begin{array}{l}1.6\left(\mathrm{AFG}_{1}\right) \text {, } \\
1.6 \text { total } \mathrm{AFs}\end{array}$ \\
\hline \multirow[t]{2}{*}{ In-shell hazelnuts } & hyper & 6 & - & - & - & - \\
\hline & small & 6 & - & - & - & - \\
\hline \multirow[t]{2}{*}{ Shell-less hazelnuts } & hyper & 6 & - & - & - & - \\
\hline & small & 6 & - & - & - & - \\
\hline \multirow[t]{2}{*}{ In-shell walnuts } & hyper & 6 & - & - & - & - \\
\hline & small & 6 & - & - & - & - \\
\hline \multirow[t]{2}{*}{ shell-less Walnuts } & hyper & 6 & - & - & - & - \\
\hline & small & 6 & - & - & - & - \\
\hline
\end{tabular}


After six months of cold storage at $7^{\circ} \mathrm{C}$ and $70 \% \mathrm{RH}, \mathrm{AFs}$ contamination appeared in only one of six shell-less almond samples, collected from small retail market $(1.6 \mu \mathrm{g} / \mathrm{kg}$ of $A F G_{1}$ form and $1.6 \mu \mathrm{g} / \mathrm{kg}$ of total $A F s$ ). These values are stfill less than the recognized maximum limited value $(8 \mu \mathrm{g} / \mathrm{kg}$ for $\mathrm{AFB}_{1}$ and $10 \mu \mathrm{g} / \mathrm{kg}$ for total $\mathrm{AFs}$ ) (European Commission, 2010). Same results were recorded by Georgiadou et al. (2012) in pistachio nuts who found that samples free from AFs at collection were free from contamination after storage under controlled conditions $\left(5-7^{\circ} \mathrm{C}\right.$ and $45-60 \%$ $\mathrm{RH})$, while contaminated samples at drying presented the same amount of AFs after storage with no significant differences. Also, Luttfullah and Hussain (2011) reported that aflatoxins contamination appeared in damaged and shell-less nuts more than inshell nuts. Saleemullah et al. (2006) found that nuts stored for long time (12-18 months) increased AFs content compared to short storage period (2-3 months). The appearance of $A F G_{1}$ in almonds samples is might be due to the invasion of nuts by $A$. parasiticus, rather than $A$. flavus (Hesseltine et al., 1970).

\section{Sensory evaluation}

Sensory evaluation before cold storage

Data presented in Table (2) showed that

Table 2: Sensory evaluation of nut samples before and after six months of cold storage.

\begin{tabular}{|c|c|c|c|c|c|c|c|c|}
\hline \multirow[t]{2}{*}{ Samples type } & \multirow[t]{2}{*}{ market } & \multirow{2}{*}{$\begin{array}{c}\text { Number } \\
\text { of } \\
\text { samples }\end{array}$} & \multicolumn{2}{|c|}{$\begin{array}{l}\text { Insect infected } \\
\text { samples }\end{array}$} & \multicolumn{2}{|c|}{$\begin{array}{l}\text { Fungal infected } \\
\text { samples }\end{array}$} & \multicolumn{2}{|c|}{ Taste score } \\
\hline & & & before & after & before & after & before & after \\
\hline \multirow[t]{2}{*}{ In-shell almond } & Hyper & 6 & - & - & - & - & ++++ & ++++ \\
\hline & small & 6 & - & - & - & - & ++++ & ++++ \\
\hline \multirow[t]{2}{*}{ Shell-less almond } & hyper & 6 & - & - & - & - & ++++ & +++ \\
\hline & small & 6 & - & 2 & - & - & ++++ & +++ \\
\hline \multirow[t]{2}{*}{ In-shell hazelnut } & hyper & 6 & - & - & - & - & ++++ & +++ \\
\hline & small & 6 & - & - & - & - & ++++ & ++ \\
\hline \multirow[t]{2}{*}{ Shell-less hazelnut } & hyper & 6 & - & 2 & - & - & +++ & ++ \\
\hline & small & 6 & 1 & 4 & - & - & ++ & + \\
\hline \multirow[t]{2}{*}{ In-shell walnut } & hyper & 6 & - & 2 & - & - & ++++ & ++++ \\
\hline & small & 6 & - & - & - & - & ++++ & +++ \\
\hline \multirow[t]{2}{*}{ shell-less Walnut } & hyper & 6 & - & 2 & - & - & ++++ & + \\
\hline & small & 6 & - & 4 & - & - & +++ & + \\
\hline
\end{tabular}

Where: ++++ Excellent; +++ very good; ++ good; + bad) before storage, the collected samples of inshell and shell-less almonds have the same excellent taste in both markets. Whereas, inshell hazelnuts and in-shell walnuts have better taste compared to the shell-less ones in both small retails and hyper-markets. The lowest taste score was found in shell-less hazelnuts, especially of small retail markets; however, taste is still acceptable. The lowest taste score of shell-less nuts may be due to the effect of shell in preventing kernel and its component from surrounding environmental conditions. Due to the high lipid content of nuts, oxidation or break down of fatty acids may take place, when nuts exposed to air, to produce secondary products such as aldehydes, ketones, alcohols, hydroxyl acids and hydrocarbons, which are often volatile components that resulted in off-flavor and off-odor (Martin et al., 2001). Insect infection was detected in one sample of shell-less hazelnuts collected from small retail, while there were no fungal infection appeared on all collected samples. This is can be explained by the findings of Embaby et al. (2012) who reported that fungal contamination occurred in the field during harvest, transport, marketing, and storage under domestic condition, whereas imported nuts must be free of insect and fungal infection to pass through quarantine. 


\section{Sensory evaluation after cold storage}

Data in Table (2) showed that after 6 months of cold storage, taste score had decreased for all nut samples except for inshell almonds of both small retail and hypermarkets, and in-shell walnuts of hypermarkets. The lowest taste score was reported with shell-less walnuts of small retail and hyper-markets, and shell-less hazelnuts of small retail markets only. Shellless nuts were more susceptible to oxidation, due to the higher contact surface to oxygen, compared to in-shell ones (Martin et al., 2001). The reduction in taste score of shell-less walnuts and shell-less hazelnuts, compared to shell-less almond may be due to their high content of total oil. Generally, oil content is the highest in walnuts, followed by hazelnuts, and then almonds (KornsteinerKrenn et al., 2013). The influence of small retail and hyper-markets on the quality of inshell and shell-less almond did not appear, while all in-shell and shell-less samples of hazelnut and walnut collected from hypermarket have higher quality in comparison to those collected from small retail markets. This is may be due to the exposure of nuts to unfavorable conditions in the small retail markets, such as high temperature and humidity, direct sun exposure, and mixed storage with other products. These findings are parallel with Martin et al. (2001) who reported that storage at low temperature $\left(4{ }^{\circ} \mathrm{C}\right.$ and $\left.78 \% \mathrm{RH}\right)$ maintains quality and good oxidative stability of almonds for at least 10 months.

Insect infection was increased after storage, mainly in shell-less ones. Almonds, hazelnuts and walnuts collected from small retails were more infected compared to nuts collected from hyper-markets (Table 2). This is due to the role of shell in protection of kernels from insects and the strict roles given in hyper-markets regard insect and rodents infection.

\section{CONCLUSIONS}

The absence of AFs in all collected samples from small retails and hypermarkets during June and July 2015 refers to the important role of quarantine to avoid AFs contamination and ensure food safety. After six months of cold storage at $7^{\circ} \mathrm{C}$, aflatoxins were detected in one sample of shell-less almond, but it is still within the safe limit, as recommended by European Commission (2010). Storage of in-shell nuts is more preferred to keep the good taste and to avoid insects and fungal infection that may results to nuts contamination with AFs. Cold storage is more suitable to avoid nuts contamination with AFs, but it is not enough to keep the good taste of the nuts. The relationship between taste quality and AFs contamination was not detected. Further studies are necessary to follow AFs contamination on other nuts and nut products for longer storage period to decrease the risk of aflatoxin contamination of nuts in the Egyptian markets.

\section{REFERENCES}

Abdulkadar, A.H.W., A. Al-Ali and J. AlJedah (2000). Aflatoxin contamination in edible nuts imported in Qatar. Food Control, 11:157-160.

AOAC, (2012). Official Methods of Analysis. Natural toxins. (Chapter 49, p.26.). Washington. D.C., USA.

Christopoulos, M.V. and E. Tsantili (2012). Storage of fresh walnuts (Juglans regia L.) - Low temperature and phenolic compounds. Postharvest Biol. Technol., 73: 80-88.

Chun, H.S., H.J. Kim, H.E. Ok, J.B. Hwang and D.H. Chung (2007). Determination of aflatoxin levels in nuts and their products consumed in South Korea. Food Chem., 102 (1): 385-391.

Deabes, M. and R. Al-Habib, 2011. Toxigenic fungi and aflatoxin associated to nuts in Saudi Arabia. J. Am. Sci., 7(8): 218-225.

Dini, A., P. Khazaeli, A. Roohbakhsh, A. Madadlou, M. Pourenamdari, L. Setoodeh, A. Askarian, N. Doraki, H. Farrokhi, H. Moradi and E. Khodadadi 
(2013). Aflatoxin contamination level in Iran's pistachio nut during years 20092011. Food Control, 30: 540-544.

Embaby, E.M., L.F. Hagagg and M.M. Abdel-Galil (2012). Decay of some fresh and dry fruit quality contaminated by some mold fungi. JASR., 8(6): 30833091.

European Commission, 2010. Commission Regulation (EC) No. $165 / 2010$ of 26 February 2010 amending Regulation (EC) No 1881/2006 setting maximum levels for certain contaminants in foodstuffs. Official Journal of the European Union.

Fani, A., M. Rezaei, A. Moini, P. Fani, P. Mirzajani, A.A. Malekirad, M. Rafeie and N. Atabak (2013). Aflatoxin occurrence in nuts consumed in Arak, Iran. Int. J. Food Nutr. Saf., 4: 91-97.

FAO, (1994). Definition and Classification of Commodities, Nuts and Derived Products.

http://www.fao.org/es/faodef/fdef05e.htm

FAO, (2013). food and agriculture organization of the United Nations statistics division. http://faostat3.fao.org.

Georgiadou, M., A. Dimou and S. Yanniotis (2012). Aflatoxin contamination in pistachio nuts: A farm to storage study. Food Control, 26: 580-586.

Hesseltine, C.W., O.L. Shotwell, M. Smith, J.J. Ellis, E. Vandegraft and G. Shannon (1970). Production of various aflatoxins by Aspergillus flavus. series. In Proceedings of the First US-Japan Conference on Toxic Microorganisms, 202-210.

Jelinek, C.F., A.E. Pohland and G.E. Wood (1989). Worldwide occurrence of mycotoxins in foods and feeds - an update. J. Assoc. Off. Anal. Chem., 72: 223-230.

Kornsteiner-Krenn, M., K.H. Wagner and I. Elmadfa (2013). Phytosterol Content and Fatty Acid Pattern of Ten Different Nut Types. Int. J. Vitam. Nutr. Res. 83 (5): 263-270.

Kris-Etherton, P.M., S. Yu-Poth, J. Sabaté, H.E. Ratcliffe, G. Zhao and T.D Etherton
(1999). Nuts and their bioactive constituents: effects on serum lipids and other factors that affect disease risk. Am. J. Clin. Nutr., 70 (suppl): 504s-511s.

Leong, Y.H., N. Ismail, A.A. Latif and R. Ahmad (2010). Aflatoxin occurrence in nuts and commercial nutty products in Malaysia. Food Control, 21: 334-338.

Leontopoulos, D., A. Siafaka and P. Markaki (2003). Black olives as substrate for Aspergillus parasiticus growth and aflatoxin B1 production. Food Microbiol., 20: 119-126.

Lopez, A., M.T Pique, A. Romero and N. Aleta (1995). Influence of cold-storage conditions on the quality of unshelled walnuts. Int J. Refrig., 18 (8): 544-549.

Luttfullah, G. and A. Hussain (2011). Studies on contamination level of aflatoxins in some dried fruits and nuts of Pakistan. Food Control, 22(3-4):426-429.

Martin, M.B.S., T. Fernandez-Garcia, A. Romero and A. Lopez (2001). Effect of modified atmosphere storage on hazelnut quality. J. Food Process. Preserv., 25: 309-321.

Raisi, M., M. Ghorbani, A.S. Mahoonak, M. Kashaninejad and H. Hosseini (2015). Effect of storage atmosphere and temperature on the oxidative stability of almond kernels during long term storage. J. Stored Prod. Res., 62: 16-21.

Rodrigues, P., A. Venancio and N. Lima (2012). Aflatoxigenic fungi and aflatoxins in Portuguese almonds. Scientific World J., 2012: 1-9.

Saleemullah, I.A., I.A. Khalil and H. Shah (2006). Aflatoxin contents of stored and artificially inoculated cereals and nuts. Food Chem., 98: 699-703.

Wild, C.P. and Y.Y. Gong (2010). Mycotoxins and human disease: a largely ignored global health issue. Carcinogenesis, 31(1): 71-82.

Zhang, W., B. Xue, M. Li, Y. Mu, Z. Chen, J. $\mathrm{Li}$ and A. Shan (2014). Screening a strain of Aspergillus niger and optimization of fermentation conditions for degradation of aflatoxin $B_{1}$. Toxins., 6(11): 31573172. 


\section{تقييم التلوث بسموم الأفلاتوكسين وجودة ثمار النقل في الأسواق المصرية ويعد التخزين البارد}

\section{هلى عبد الرحمن عبد الرحمن جلال}

معهد الدراسات والبحوث البيئية، جامعة مدينة السادات، المنوفية ، مصر

الملخص العربى

تتعرض ثمار النقل فى مراحل ما قبل الحصاد اوبعد الحصاد واثثاء التخزين للاصابة ببعض الفطريات المنتجة للافلاتوكسينات، والافلاتوكسينات هى احدى المنتجات الثانوية لعملية الايض الغذائى لهذه الفطريات السامة وتسبب هذه السموم اضرار بالغة لصحة الانسان والحيوان ـ اجريت هذه الدراسة بغرض تقييم جودة بعض انواع النقل التى تستورد من الخارج وتطرح فى الاسواق المصرية وتقدير محتواها من سموم الافلاتوكسين وذلك خلال شهرى يونيو ويوليو 2015 ( طوال شهر رمضان) حيث تعتبر هذه الفترة هى الموسم الرئيسى لاستهلاك ثمار النقل

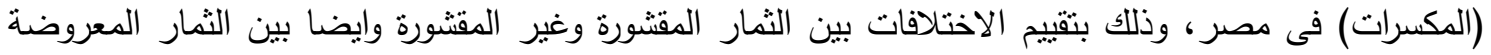
فى اسواق التجزئة الصغيرة والاسواق الكبيرة وتحديد العلاقة بين جودة الثمار الظاهرية ومحتواها من سموم الافلاتوكسين وايضا لتقييم تأثثر التخزين البارد على تغير صفات الجودة ومحتوى الافلاتوكسين فى هذه الثمار . تم جمع 72 عينة من ثلاثة انواع من النقل ( اللوز والبندق والجوز) سواء المقتورة وغير المقشورة من اسواق التجزئة الصغيرة والاسواق الكبيرة بعدة محافظات مصرية واجرى تقييم لجودة الثماربالنسبة للمستهلك ودرجة الاصابة بالحشرات والفطريات. نم قياس التلوث بسموم الافلاتوكسين الكلية وافلاتوكسين G1, G2, B1, B2 باستخدام جهاز جهاز تحليل كروماتوجرافي عالي الكفاءة HPLC وذلك فى عينات النقل بعد جمعها من الاسواق مباشرة، ثم

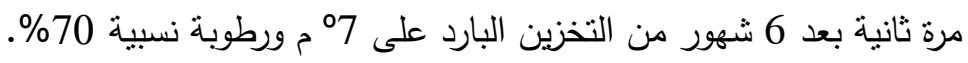
اظهرت النتائج تدهور جودة ثمار النقل بعد التخزين وخاصة فى الجوز المقتور والبندق المقشور مقارنة بباقى العينات. كما اظهرت خلو جميع العينات سواء المقشورة اوغير المقشورة ،والمجموعة من كلا من اسواق التجزئة والاسواق الكبيرة من التلوث بسموم الافلاتوكسين، بينما بعد مرور 6 شهور من التخزين البارد ظهر التلوث بافلاتوكسين G1 بنسبة 1,6 ميكروجرام /كجم فى عينة واحدة من اللوز المقتور (هذه القيمة اقل من الحدود

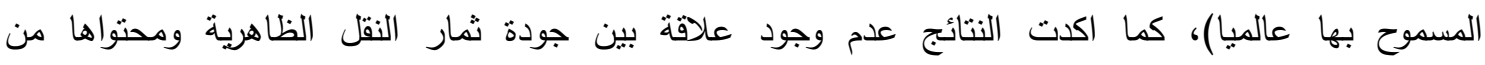
الافلاتوكسين. وقد اوصت النتائج بتخزين ثمار النقل غير المقتورة بدلا من تخزينها مقشورة، وذلك للحفاظ على الطعم الجيد

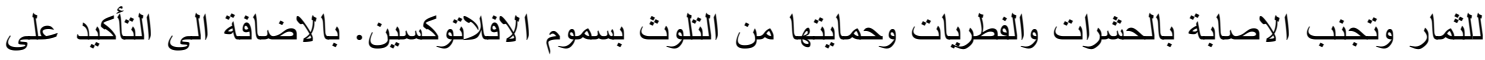

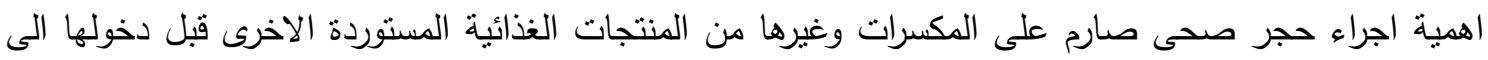
الاسواق المصرية لضمان سلامة الاغذية وخلوها من سموم الافلاتوكسين. 